\title{
Linking Empowering Leadership, Psychological Empowerment, Self-Leadership, Creative Involvement and Creativity: A Sequential Mediation Model
}

\section{Ishfaq Ahmed, ${ }^{*}$ Muhammad Khalid Khan ${ }^{* *}$ and Ghulam Ali Bhatti $^{* *}$}

\begin{abstract}
This study examines the relationship between empowering leadership and employee creativity through the serial mediating role of psychological empowerment and self-leadership with creative work involvement. Applying a chain mediation approach to a sample of 314 respondents, we find that empowering leadership has a significant effect on the selected mediators (self-leadership, psychological empowerment and creative work involvement), which in turn transfer this effect to employee creativity.
\end{abstract}

Keywords: empowering leadership, self-leadership, psychological empowerment, creative work involvement, creativity, serial mediation.

JEL classification: C12, C31, D23, M10, O31.

\section{Introduction}

The idea of achieving the best possible employee attitudes and behaviors has gained significance in the last few decades and changed how organizations handle their human resources. This has resulted in a shift in organizational work design in terms of autonomy, self-leadership, delegation and empowerment (Pyoria, 2005). It is also evident that empowerment tends to yield positive outcomes both for individuals and organizations (Seibert, Silver \& Randolph, 2004).

The concept of employee empowerment is led by two distinct schools of thought. The socio-structural perspective focuses on the interventions and practices implemented by leaders, managers and

\footnotetext{
* Assistant professor, Hailey College of Commerce, University of the Punjab, Lahore.

** Registrar, University of the Punjab, Lahore.

*** Associate professor and chairperson, Department of Commerce, University of Gujrat.
} 
organizations to empower their employees. The psychological perspective is rooted in the perceptions that employees develop about their own contribution to, and role in, an organization (Spreitzer, 1995, 2008; Bennis \& Nanus, 1985; Lawler, 1986). Together, both approaches operationalize the concept of psychological empowerment (PE) in terms of employees' perception of, and response to, the conditions of structural empowerment (Laschinger et al., 2004).

In looking at ways to empower employees, a key factor is the role of the leader. Leaders find different - and often original - ways to influence their followers, one of which involves empowering leadership (EL) (Ahearne, Mathieu \& Rapp, 2005; Amundsen \& Martinsen, 2014). According to Manz and Sims (1991, 2001), an empowering leader is one who equips others to lead themselves and who is willing to share power with his/her followers (see Randolph \& Kemery, 2011; Vecchio, Justin \& Pearce, 2010).

The EL approach is linked to the concept of super-leadership (Manz \& Sims, 2001) - creating leaders among one's followers -and of selfleadership (SL) among employees. SL is defined as the process of governing one's behavior through various cognitive and behavioral strategies (Neck \& Houghton, 2006). While it is valuable in itself, Stewart, Courtright and Manz (2011) comment that SL is not a substitute for external leadership. This makes it important to study the role of EL as a facilitator of SL.

The literature presents ample evidence of EL as a key predictor of PE and SL among employees. Amundsen and Martinsen's (2014) pioneering study, for instance, shows that both PE and EL are tied to the concept of employee empowerment. An important aspect of EL is that of building a culture of empowering one's followers to become self-leaders. The outcomes of this style of leadership are often better than ordinary job outcomes. Randolph and Kemery (2011) observe that empowering leaders influence their followers in two ways: by adding value to and empowering the latter psychologically, and by creating leaders among followers. Zhang and Bartol (2010) underscore the role of empowering leaders in creating leadership roles for individuals through PE.

Although many studies have examined the mediating role of PE in the relationship between EL and employee outcomes, the mediating role of SL remains under-investigated (see Amundsen \& Martinsen, 2014, 2015). Moreover, while studies such as Singh and Sarkar (2012) have assessed the 
relationship between PE and job involvement, the literature on EL in this context is scanty. Drawing on emotional regulation theory (ERT), this study looks at SL and PE as mediating variables in the relationship between EL and creative work involvement (CWI).

\section{Literature Review}

The foremost relationship we examine here concerns EL and SL (among employees). Although this has received little empirical attention, we consider Amundsen and Martinsen's $(2014,2015)$ argument that the role of employee empowerment lies in making employees self-dependent and able to self-lead. SL encompasses the skills and tactics used by individuals to propel themselves toward achieving higher levels of effectiveness and performance (Amundsen \& Martinsen, 2014; Manz, 1986).

According to Manz and Sims (2001), SL can be grouped into three distinct strategies: (i) natural reward-focused, (ii) behavior-focused and (iii) constructive thought patterns. Natural reward strategies entail intrinsic motivation, enjoyability, activities leading to pleasure and redesigning a job accordingly (Houghton \& Neck, 2002). Behavioral strategies include setting goals and directing, observing, rewarding, correcting and appraising oneself (Manz \& Neck, 2004). Constructive thought patterns refer to valuing one's performance in terms of success, positive self-talk, changing one's thinking patterns and reinforcing self-belief (Houghton \& Neck, 2002). Martinsen (2009), however, criticizes the conventional concept of SL as being individual-oriented with restricted application to work settings. This implies that the concept must be expanded to include such aspects as coordinated effort and self-effort and creative thought processes with a view to meeting task requirements.

The association can be framed in terms of Hochschild's (1983) ERT, which refers to the cognitive appraisal and physiological stimulation of a situation, which are then regulated to meet the demands of an organization. Thus, employees manage their emotions to fit the workplace (for example, leading to job satisfaction). Gross (1998a, b) develops a model of emotional regulation at the workplace that engenders the idea of 'emotional labor'. Under this model, the input of external forces (an organization or leaders) serve as a stimulus, to which individuals respond in the shape of emotions.

Based on this theoretical premise, we can assume that, when leaders empower their followers (the stimulus), employees respond by 
developing their capacity for SL. The theoretical and empirical literature includes numerous studies on the positive association between EL and SL (see, for example, Amundsen \& Martinsen, 2014, 2015; Houghton \& Yoho, 2005; Tekleab et al., 2008; Yun, Cox \& Sims, 2006). Based on this, we present the following hypothesis (H1): EL will positively predict $S L$.

As with PE, SL can be a significant predictor of employee creativity. Noting the dearth of literature in this area, Stewart et al. (2011) emphasize its importance as an avenue for research, in response to which Amundsen and Martinsen (2015) investigate the role of SL in predicting employee creativity and find a strong association between the two variables. This relationship can also be framed in terms of ERT, such that EL, supported by SL (the stimulus), spurs employee creativity (the response).

While some studies have focused on the direct impact of SL on employee creativity, they do not consider the mechanism through which this relationship operates. We examine this association on the premise that self-regulation and empowerment among employees - both dimensions of SL - influence their level of energy and intrinsic motivation at work (see Atwater \& Carmeli, 2009; Amabile, 1983). Greater $\mathrm{SL}$ in the form of self-regulation and empowerment will yield better employee outcomes in terms of creativity. Thus, our second hypothesis $(\mathrm{H} 2)$ is that EL has an indirect influence over employee creativity through the mediating roles of SL and CWI.

Drawing on Thomas and Velthouse (1990), we consider PE a form of intrinsic motivation to work. Several factors underpin the association between PE and EL. The first pertains to the role of empowering leaders who create a sense of meaningful work by sharing their goals and objectives with employees (Conger \& Kanungo, 1988). The second factor involves the extent to which leaders share power, delegate responsibilities, offer autonomy and encourage employees to participate in decision making at work (Amundsen \& Martinsen, 2014; Manz \& Sims, 1987).

Empowering leaders also generate positive self-perception among employees with respect to the latter's competence by providing encouragement, emotional support, performance models and positive persuasion (Bandura, 1986). This relationship has garnered substantial empirical support in the literature (see, for example, Amundsen \& Martinsen, 2014, 2015; Boudrias et al., 2009; Seibert, Wang \& Courtright, 2011; Randolph \& Kemery, 2011; Raub \& Robert, 2010). Accordingly, we present the following hypothesis (H3): EL positively predicts employees' PE. 
Finally, we investigate the impact of PE and SL on employee creativity. While numerous studies observe that $\mathrm{PE}$ has a positive influence on employees' job-related attitudes, including their job satisfaction and performance (see Seibert et al., 2011; Castro, Periñan \& Bueno, 2008; Dewettinck \& van Ameijde, 2011; Hechanova, Alampay \& Franco, 2006; and Seibert et al., 2004), not many have examined the relationship between empowerment and creativity (see Zhang \& Bartol, 2010; Spreitzer, De Janasz \& Quinn, 1999; Spreitzer, 1995). PE is considered the source of intrinsic task motivation (Thomas \& Velthouse, 1990) and the foremost determinant of creativity at the workplace (Amabile, 1983).

Atwater and Carmeli (2009) argue that effective (empowering) leaders can energize their employees into higher levels of CWI. Vanichchinchai (2012) supports this thesis, observing that employees with higher levels of involvement deliver better task-related performance. This points to a positive relationship between employees' CWI and their creative performance. Thus, our fourth hypothesis (H4) is that EL indirectly influences employee creativity through the mediating roles of PE and CWI.

\section{Research Methodology}

Our sample was drawn from employees working at information technology firms, where creativity is a key aspect of performance. The study targeted 53 software firms employing 789 employees (78 percent in permanent positions and 22 percent on contract). We contacted 417 employees (45 percent contractual, 55 percent permanent) for permission to conduct a survey, of which 329 respondents agreed to complete the survey questionnaire. Since 15 questionnaires had to be discarded because they had been incorrectly filled or left incomplete, we were left with a sample of 314 usable responses for analysis. Of the sample, 12.8 percent comprised team leaders, 85.69 percent were male and 63.67 percent had less than a year's experience.

The survey instruments are adapted from existing studies. Creativity is measured using a 13-item scale drawn from George and Zhou (2001), which includes items such as "I am a good source of creative ideas". To operationalize CWI, we use a nine-item scale adapted from Tierney, Farmer and Graen (1999), with items such as "I have demonstrated originality at my workplace". The 20-item scale used by Amundsen and Martinsen (2015) measures SL, with items such as "I offer to take on tasks when I feel well qualified to carry them out". Spreitzer's (1995) 12-item scale measuring PE gauges items such as "the work I do is very important 
to $\mathrm{me}^{\prime \prime}$. EL is operationalized using an 18-item scale adapted from Amundsen and Martinsen (2014), with items such as "my leader provides guidance on how I can do my work in the best possible way". All these measures are characterized by an acceptable level of internal consistency $(\infty=0.79-0.94)$.

We use structural equation modeling to carry out a confirmatory factor analysis and gauge the validity of the constructs. The results of the goodness-of-fit tests indicate that a five-factor model is better than a singlefactor model (one-factor model: $\mathrm{x} 2=792.531, \mathrm{df}=325$, SRMR $=0.09, \mathrm{CFI}=$ 0.72, RMSEA $=0.09$; five-factor model: $\mathrm{x} 2=932.152, \mathrm{df}=349, \mathrm{SRMR}=0.06$, $\mathrm{CFI}=0.90$, RMSEA $=0.02$ ). The constructs are deemed discriminant and independent. Additionally, the acceptable factor loadings (0.53-0.91, p < 0.001) indicate good convergent validity (AVE > 0.50; see Hair et al., 2010).

\section{Results}

Table 1 shows that the reliability statistics fall within the acceptable range (0.81-0.93 > 0.70; see Nunnally, 1978), confirming that the measures used are reliable. The bivariate correlation analysis reveals that all the variables are positively and significantly correlated. Since we can see that none of the demographic variables is significantly correlated with the criterion variable, they do not need any further treatment.

Table 1: Descriptive statistics

\begin{tabular}{|c|c|c|c|c|c|c|c|c|c|c|c|}
\hline & & $\begin{array}{l}\text { Mean } \\
\text { (SD) }\end{array}$ & 1 & 2 & 3 & 4 & 5 & 6 & 7 & 8 & 9 \\
\hline 1 & EL & $\begin{array}{c}4.01 \\
(0.92)\end{array}$ & $(0.814)$ & & & & & & & & \\
\hline 2 & SL & $\begin{array}{c}3.88 \\
(0.93)\end{array}$ & $0.453^{* *}$ & $(0.810)$ & & & & & & & \\
\hline 3 & PE & $\begin{array}{c}3.99 \\
(0.68)\end{array}$ & $0.496^{*}$ & $0.125^{*}$ & $(0.829)$ & & & & & & \\
\hline 4 & CWI & $\begin{array}{c}3.93 \\
(0.84)\end{array}$ & $0.389^{* *}$ & $0.304^{*}$ & $0.493^{*}$ & $(0.930)$ & & & & & \\
\hline 5 & Creativity & $\begin{array}{c}3.91 \\
(0.69)\end{array}$ & $0.301^{* *}$ & $0.412^{* *}$ & $0.245^{* *}$ & $0.419^{*}$ & (0.929) & & & & \\
\hline 6 & Age & $\begin{array}{l}27.12 \\
(8.52)\end{array}$ & -0.008 & 0.020 & 0.008 & 0.017 & 0.015 & $0.009^{*}$ & - & & \\
\hline 7 & Gender & & 0.045 & $-0.010^{* *}$ & $-0.012^{* *}$ & 0.035 & $0.010^{* *}$ & 0.015 & 0.054 & & \\
\hline 8 & Qualifications & & 0.013 & -0.012 & $0.021^{* *}$ & $0.009^{* *}$ & $0.022^{* *}$ & 0.004 & 0.017 & - & \\
\hline 9 & $\begin{array}{l}\text { Experience } \\
\text { with current } \\
\text { employer }\end{array}$ & $\begin{array}{c}4.15 \\
(2.17)\end{array}$ & $0.009^{* *}$ & $0.037^{* *}$ & $0.005^{* *}$ & 0.074 & $0.018^{* *}$ & 0.028 & 0.023 & 0.021 & - \\
\hline
\end{tabular}

Note: $\mathrm{N}=314,{ }^{*} \mathrm{p}>0.001,{ }^{* *} \mathrm{p}>0.05$.

Source: Authors' estimates. 
Linking Empowering Leadership, Psychological Empowerment, Self-Leadership, 73 Creative Involvement and Creativity: A Sequential Mediation Model

Table 2 shows that the structural model fits the data. The study's hypothesis-testing results are presented in Tables 3 and 4, in which we use Preacher and Hayes' process macros for the serial mediation analysis.

Table 2: Structural equation model results

\begin{tabular}{lcl}
\hline & Standard value & \multicolumn{1}{c}{ Direct effect } \\
\hline $\mathrm{x} 2$ & $\geq 0.90$ & $795.32(\mathrm{df}=349)$ \\
GFI & $\geq 0.80$ & 0.944 \\
AGFI & $\geq 0.90$ & 0.878 \\
CFI & $\geq 0.90$ & 0.845 \\
NFI & $\geq 0.90$ & 0.890 \\
NNFI & $\leq 0.08$ & 0.912 \\
RMSEA & 0.050 \\
\hline
\end{tabular}

Source: Authors' estimates.

The results show that EL has a significant effect on creativity $(\beta=$ $0.0945, \mathrm{p}<0.05)$ and that all the paths are significant. Since the EL path to creativity, mediated by SL and CWI, is significant (a1d2b1 $\beta=0.0358, \mathrm{CI}=$ 0.1247 to 0.0985 ), we can conclude that the relationship between EL and creativity is explained by the chain mediation of SL and CWI. This finding supports both $\mathrm{H} 1$ and $\mathrm{H} 2$. The results also support the presence of serial mediation by PE and CWI (a1d2b1 $\beta=0.0113, \mathrm{CI}=0.1195$ to 0.0971 ), thus supporting $\mathrm{H} 3$ and $\mathrm{H} 4$.

Table 3: Serial mediation analysis (EL-SL-CWI-C)

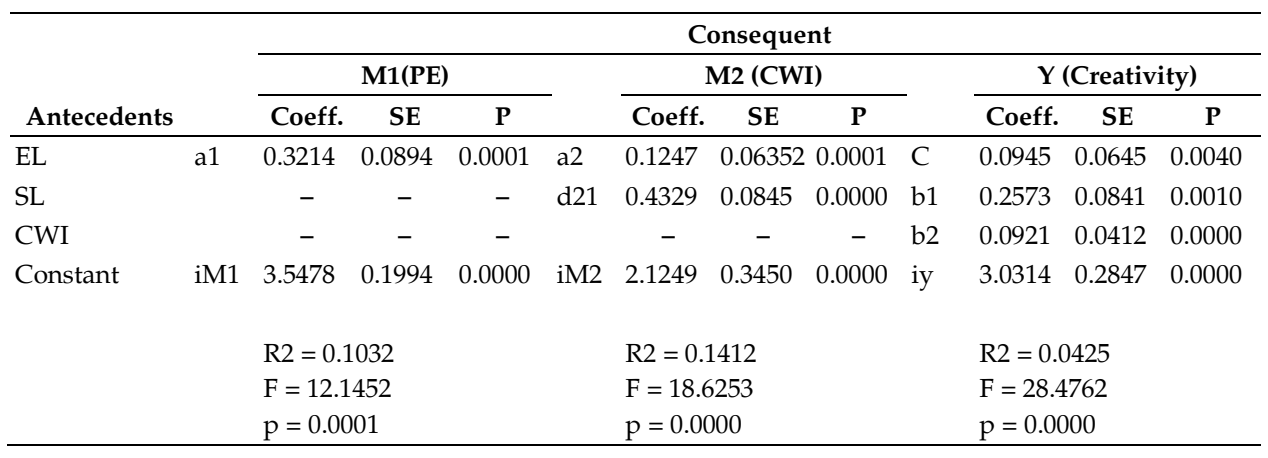

Source: Authors' estimates. 
Table 4: Serial mediation analysis (EL-PE-CWI-C)

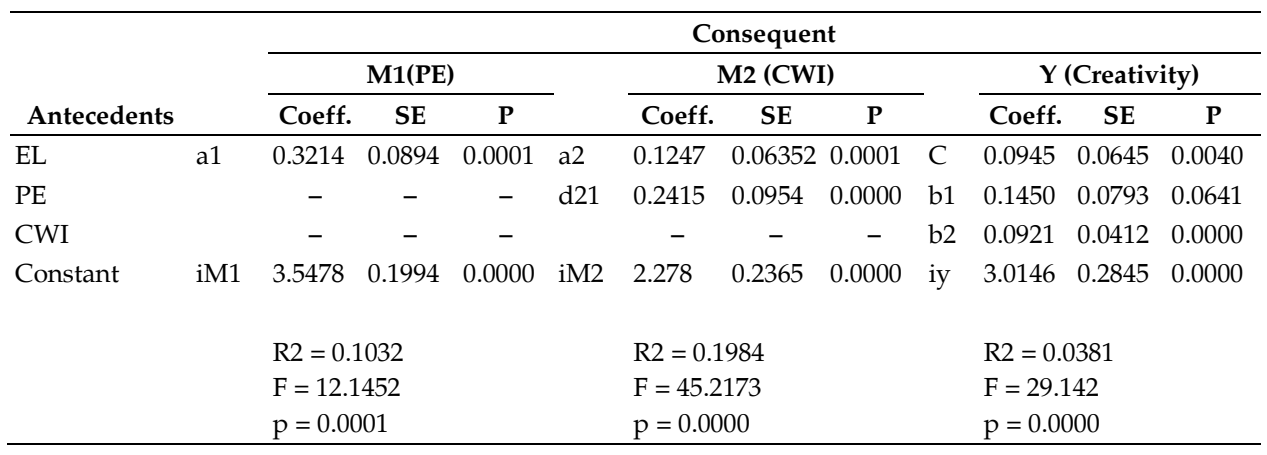

Source: Authors' estimates.

\section{Discussion}

Drawing on ERT, we assume that EL influences employees by increasing their creativity through the sequential mediation of SL/PE and CWI. We test this using four hypotheses.

The first hypothesis states that EL has a positive effect on employees by developing their SL skills. Our results support this hypothesis in line with ERT as well as other studies, including Amundsen and Martinsen (2014, 2015); Houghton and Yoho (2005); Tekleab et al. (2008); and Yun et al. (2006). The second hypothesis states that EL affects employee creativity through the serial mediation of SL and CWI. Although the literature does not focus on this relationship, our results support the hypothesis, consistent with ERT.

Finally, our results support the third and fourth hypotheses, which state that EL influences PE among employees. This is consistent with Amundsen and Martinsen (2014, 2015); Boudrias et al. (2009); Randolph and Kemery (2011); Raub and Robert (2010); and Seibert et al. (2011). Our findings also reflect the assumptions we have drawn from ERT, which state that employees' emotions are directed by the stimuli offered by their organization and leaders - to which employees respond in the form of greater SL and creativity.

\section{Conclusion}

This study examines the serial mediation mechanism of PE/SL and CWI among employees, through which EL is tied to higher levels of creativity at the workplace. Our findings show that the impact of EL is 
Linking Empowering Leadership, Psychological Empowerment, Self-Leadership, 75 Creative Involvement and Creativity: A Sequential Mediation Model

transmitted to employees when they perceive an increase in their levels of PE and SL; this enhances their creativity through the mediation of CWI. In other words, leadership style can influence creativity by enhancing the selfbelief and positive psychological state of followers as well as their belief in their own capacity for leadership and their creative ability and involvement.

The study's results are subject to several limitations. These include its limited sample size and cross-sectional nature, which raises the possibility of common method variance. Attempts to replicate the study should address these limitations, consider additional relationships such as between SL and PE, and incorporate other leadership styles and variables (such as energy) into the chain mediation process. 


\section{References}

Ahearne, M., Mathieu, J., \& Rapp, A. (2005). To empower or not to empower your sales force? An empirical examination of the influence of leadership empowerment behavior on customer satisfaction and performance. Journal of Applied Psychology, 90(5), 945-955.

Amabile, T. M. (1983). The social psychology of creativity: A componential conceptualization. Journal of Personality and Social Psychology, 45(2), 357-376.

Amundsen, S., \& Martinsen, O. L. (2014). Empowering leadership: Construct clarification, conceptualization, and validation of a new scale. Leadership Quarterly, 25(3), 487-511.

Amundsen, S., \& Martinsen, O. L. (2015). Linking empowering leadership to job satisfaction, work effort, and creativity: The role of selfleadership and psychological empowerment. Journal of Leadership and Organizational Studies, 22(3), 1-20.

Atwater, L., \& Carmeli, A. (2009). Leader-member exchange, feelings of energy, and involvement in creative work. Leadership Quarterly, 20(3), 264-275.

Bandura, A. (1986). Social foundations of thought and action: A social cognitive theory. Englewood Cliffs, NJ: Prentice-Hall.

Bennis, W. G., \& Nanus, B. (1985). Leaders: Strategies for taking charge. New York: Harper \& Row.

Boudrias, J.-S., Gaudreau, P., Savoie, A., \& Morin, A. J. S. (2009). Employee empowerment: From managerial practices to employees' behavioral empowerment. Leadership and Organization Development Journal, 30(7), 625-638.

Castro, C. B., Periñan, M. M. V., \& Bueno, J. C. C. (2008). Transformational leadership and followers' attitudes: The mediating role of psychological empowerment. International Journal of Human Resource Management, 19(10), 1842-1863. 
Linking Empowering Leadership, Psychological Empowerment, Self-Leadership, 77 Creative Involvement and Creativity: A Sequential Mediation Model

Conger, J. A., \& Kanungo, R. N. (1988). The empowerment process: Integrating theory and practice. Academy of Management Review, 13(3), 471-482.

Dewettinck, K., \& van Ameijde, M. (2011). Linking leadership empowerment behavior to employee attitudes and behavioral intentions: Testing the mediating role of psychological empowerment. Personnel Review, 40(3), 284-305.

George, J. M., \& Zhou, J. (2001). When openness to experience and conscientiousness are related to creative behavior: An interactional approach. Journal of Applied Psychology, 86(3), 513524.

Gross, J. J. (1998a). Antecedent- and response-focused emotion regulation: Divergent consequences for experience, expression and physiology. Journal of Personality and Social Psychology, 74(1), 224237.

Gross, J. J. (1998b). The emerging field of emotion regulation: An integrative review. Review of General Psychology, 2(3), 271-299.

Hair, J. F., Black, W. C., Babin, B. J., \& Anderson, R. E. (2010). Multivariate data analysis (7th ed.). Upper Saddle River, NJ: Prentice Hall.

Hechanova, M. R. M., Alampay, R. B. A., \& Franco, E. P. (2006). Psychological empowerment, job satisfaction and performance among Filipino service workers. Asian Journal of Social Psychology, 9(1), 72-78.

Hochschild, A. R. (1983). The managed heart: Commercialization of human feeling. Berkeley, CA: University of California Press.

Houghton, J. D., \& Neck, C. P. (2002). The revised self-leadership questionnaire: Testing a hierarchical factor structure for selfleadership. Journal of Managerial Psychology, 17(8), 672-691.

Houghton, J. D., \& Yoho, S. K. (2005). Toward a contingency model of leadership and psychological empowerment: When should selfleadership be encouraged? Journal of Leadership and Organizational Studies, 11(4), 65-83. 
Laschinger, H. K. S., Finegan, J. E., Shamian, J., \& Wilk, P. (2004). A longitudinal analysis of the impact of workplace empowerment on work satisfaction. Journal of Organizational Behavior, 25(4), 527-545.

Lawler, E. E. (1986). High-involvement management. San Francisco, CA: Jossey-Bass.

Manz, C. C. (1986). Self-leadership: Toward an expanded theory of selfinfluence processes in organizations. Academy of Management Review, 11(3), 585-600.

Manz, C. C., \& Neck, C. P. (2004). Mastering self-leadership: Empowering yourself for personal excellence (3rd ed.). Upper Saddle River, NJ: Prentice-Hall.

Manz, C. C., \& Sims, H. P., Jr. (1987). Leading workers to lead themselves: The external leadership of self-managing work teams. Administrative Science Quarterly, 32(1), 106-129.

Manz, C. C., \& Sims, H. P., Jr. (1991). Superleadership: Beyond the myth of heroic leadership. Organizational Dynamics, 19(4), 18-35.

Manz, C. C., \& Sims, H. P., Jr. (2001). The new superleadership: Leading others to lead themselves. San Francisco, CA: Berrett-Koehler.

Martinsen, O. L. (2009, May). Self-leadership: An expanded theory, a new selfleadership inventory, and some research findings. Paper presented at the 14th European Congress of Work and Organizational Psychology, Santiago de Compostela, Spain.

Neck, C. P., \& Houghton, J. D. (2006). Two decades of self-leadership theory and research: Past developments, present trends, and future possibilities. Journal of Managerial Psychology, 21(4), 270-295.

Nunnally, J. C. (1978). Psychometric theory (2nd ed.). New York: McGraw-Hill.

Pyoria, P. (2005). The concept of knowledge work revisited. Journal of Knowledge Management, 9(3), 116-127.

Randolph, W. A., \& Kemery, E. R. (2011). Managerial use of power bases in a model of managerial empowerment practices and employee psychological empowerment. Journal of Leadership and Organizational Studies, 18(1), 95-106. 
Raub, S., \& Robert, C. (2010). Differential effects of empowering leadership on in-role and extra-role employee behaviors: Exploring the role of psychological empowerment and power values. Human Relations, 63(11), 1743-1770.

Seibert, S. E., Silver, S. R., \& Randolph, W. A. (2004). Taking empowerment to the next level: A multiple-level model of empowerment, performance, and satisfaction. Academy of Management Journal, 47(3), 332-349.

Seibert, S. E., Wang, G., \& Courtright, S. H. (2011). Antecedents and consequences of psychological and team empowerment in organizations: A meta-analytic review. Journal of Applied Psychology, 96(5), 981-1003.

Singh, M. and Sarkar, A. (2012). The relationship between psychological empowerment and innovative behavior: A dimensional analysis with job involvement as mediator. Journal of Personnel Psychology, 11(3), 127-137.

Spreitzer, G. M. (1995). Psychological empowerment in the workplace: Dimensions, measurement, and validation. Academy of Management Journal, 38(5), 1442-1465.

Spreitzer, G. M. (2008). Taking stock: A review of more than twenty years of research on empowerment at work. In C. Copper \& J. Barling (eds.), Handbook of organizational behavior (pp. 54-72). Thousand Oaks, CA: SAGE.

Spreitzer, G. M., De Janasz, S. C., \& Quinn, R. E. (1999). Empowered to lead: The role of psychological empowerment in leadership. Journal of Organizational Behavior, 20(4), 511-526.

Stewart, G. L., Courtright, S. H., \& Manz, C. C. (2011). Self-leadership: A multilevel review. Journal of Management, 37(1), 185-222.

Tekleab, A. G., Sims, H. P., Jr., Yun, S., Tesluk, P. E., \& Cox, J. (2008). Are we on the same page? Effects of self-awareness of empowering and transformational leadership. Journal of Leadership and Organizational Studies, 14(3), 185-201. 
Thomas, K. W., \& Velthouse, B. A. (1990). Cognitive elements of empowerment: An 'interpretive' model of intrinsic task motivation. Academy of Management Review, 15(4), 666-681.

Tierney, P., Farmer, S. M., Graen, G. B. (1999). An examination of leadership and employee creativity: The relevance of traits and relationships. Personnel Psychology, 52(3), 591-620.

Vanichchinchai, A. (2012). The relationship between employee involvement, partnership management and supply performance: Findings from a developing country. International Journal of Productivity and Performance Management, 61(2), 157-172.

Vecchio, R. P., Justin, J. E., \& Pearce, C. L. (2010). Empowering leadership: An examination of mediating mechanisms within a hierarchical structure. Leadership Quarterly, 21(3), 530-542.

Yun, S., Cox, J., \& Sims, H. P., Jr. (2006). The forgotten follower: A contingency model of leadership and follower self-leadership. Journal of Managerial Psychology, 21(4), 374-388.

Zhang, X., \& Bartol, K. M. (2010). Linking empowering leadership and employee creativity: The influence of psychological empowerment, intrinsic motivation, and creative process engagement. Academy of Management Journal, 53(1), 107-128. 